\title{
Regeneration of nonfunctional Macronet MN 200 loaded with metal complex dye using alcohols in batch and column experiments
}

\author{
Danutė Kaušpèdiené $\dot{1}^{*}$, \\ Audronè Gefeniené $\dot{e}^{1,2}$, \\ Romas Ragauskas ${ }^{1}$, \\ Rima Binkiené $\dot{1}^{1}$ \\ ${ }^{1}$ Institute of Chemistry of Center \\ for Physical Sciences and Technology, \\ Sauletekio Ave. 3, \\ 10257 Vilnius, Lithuania \\ ${ }^{2}$ Vytautas Magnus University, \\ K. Donelaičio St. 58, \\ 44248 Kaunas, Lithuania
}

\begin{abstract}
The conditions for reuse of the Macronet MN 200 by removing the metal complex dye Lanasyn Navy M-DNL ( $\mathrm{LnCr}$ ) from water solutions have been investigated. The Macronet MN 200 loaded with the $\mathrm{LnCr}$ dye has been regenerated using alcohols (methanol, ethanol and 2-propanol) in batch and column experiments. The FTIR spectrum of the Macronet MN 200 loaded with the LnCr dye confirmed physical interactions between the $\mathrm{LnCr}$ anion and Macronet MN 200 involving $\pi-\pi$ and electrostatic bonds. In the batch experiments the desorption efficiency of $\mathrm{LnCr}$ dye depends on the solid/liquid ratio $(\mathrm{S} / \mathrm{L}, \mathrm{g} / \mathrm{mL})$, molecular mass of alcohol and duration of desorption. The $\mathrm{LnCr}$ dye has been desorbed most efficiently after $10 \mathrm{~min}$ at $\mathrm{S} / \mathrm{L}=0.033$, while the desorption efficiency decreases with the increase of alcohol molecular weight: methanol $>$ ethanol $>2$-propanol. The rates of desorption were quantified using second-order $\left(k_{2}\right)$, pore diffusion $\left(\mathrm{D} / \mathrm{r}^{2}\right)$ and intraparticle diffusion $\left(k_{i}\right)$ models. The column test results showed that the regeneration efficiency of MN 200 loaded with the $\mathrm{LnCr}$ dye $\left(R_{e}\right)$ using methanol with repeated adsorption/desorption cycles decreased but seems to be stabilized to $70 \%$ after 3 cycles. A very high LnCr dye concentration in methanol (about $4 \mathrm{~g} / \mathrm{L}$ ) has been obtained within the first 2 alcohol bed volumes and the $\mathrm{LnCr}$ dye has been completely desorbed back to the solution with 10 alcohol bed volumes.
\end{abstract}

Keywords: chromium complex azo dye, Macronet MN 200, sorption, desorption, alcohol, kinetics

\section{INTRODUCTION}

Metal complex azo dyes used for dyeing of carpets, wool, polyamide, nylon, polyester fiber as well as for anodizing industry often pose environment problems arising from inadequately treated wastewater discharged into environmental water bodies [1, 2]. This is related to the discharged coloured water and to the hazardous carcinogenic properties of heavy metals and amines formed by reductive cleavage of azo groups of dyes [3-5]. Therefore,

\footnotetext{
* Corresponding author. Email: danute.kauspediene@ftmc.lt
}

a complete removal of these hazardous dyes from wastewaters is necessary [6, 7]. This is most commonly achieved by using the sorption method.

Activated carbon is widely used as an adsorbent due to its high surface area and high adsorption capacity. Adsorption on activated carbon of cationic and anionic dyes, acid and reactive dyes has been investigated by a number of researchers [8-12]. There are some problems using activated carbon, e.g. high regeneration costs and production of fines due to the brittle nature [13]. One of the possibilities to overcome this problem is the use of improved synthetic porous polymeric 
adsorbents, especially with a hypercrosslinked structure. Because of their higher physicochemical stabilities and better regeneration properties, these have been commercialized as alternatives to activated carbon [14].

The sorbents with a hypercrosslinked structure, including the family of Macronet and PuroSorb from Purolite, provide macroporosity and microporosity at the same time. This means to have a control on the pore size and relatively high surface areas (1000-2000 $\left.\mathrm{m}^{2} \mathrm{~g}^{-1}\right)$. Moreover, they will retain their swollen-state porosity and, hence, show little or no change in swelling with change of the permeating liquid, unlike the conventional porous polymeric sorbents [15, 16]. It should be mentioned that hypercrosslinked sorbents contain by-product residues of the crosslinking reaction as oxygen- and chlorine-containing functional groups, which increase the surface polarity and hydrophilicity, and may enhance the sorption of polar sorbates [17].

The study on the reusability and regeneration of the sorbent receives a special scientific consideration caused by practical and environmental interests. For these reasons, innovative technologies are being developed concerned with not only the economy and efficiency of regeneration but also its environmental consequences. In the case of dyes, a financially beneficial adsorption process requires as much as possible removal of dye per unit of adsorbent mass. This can be achieved through successive adsorption-desorption steps [18, 19]. Furthermore, desorption strongly influences the techno-economical value of the adsorption process. Regeneration attempts to remove dyes retained on adsorbent surfaces to restore the adsorptive capacity without modifying porosity or causing adsorbent mass losses. By this way, regeneration produces valuable products and avoids contamination. Moreover, desorption study often helps to clarify the nature of the adsorption and recycling of the dye-saturated adsorbent [20].

For the efficient dye recovery from nonfunctionalized Macronet and PuroSorb resins it is suggested to use various alcohols as regenerants [21]. Alcohols or acetone are usually preferred as regenerants since they increase the solubility of the dye molecule into the regenerant/eluent and are safer to use than other organic solvents. The regenera- tion of the nonfunctionalized Macronet 200 and weakly basic Macronet 300 sorbents saturated with azo dye Acid Red 14 was evaluated using sodium hydroxide aqueous solutions and mixtures of ethanol and acetone with water (50:50) [22]. It was concluded that the use of organic solvents provides a more efficient desorption. The whole amount of Acid Red 14 was completely eluted from MN200 and close to 80\% from MN 300. Partial elution of MN 300 resins was associated to the role of anion exchange groups in MN 300. For the nonfunctionalized polymeric sorbents Amberlite XAD 1180 saturated with C. I. Basic Blue 3 the most effective eluants were obtained: $1 \mathrm{M} \mathrm{HCl}$ in $90 \%$ methanol as well as $90 \%$ methanol [23].

This study presents the desorption test of the Lanasyn Navy M-DNL dye ( $\mathrm{LnCr}$ ) from the hypercrosslinked nonfunctionalized $\mathrm{Ma}$ cronet MN 200 using alcohols. In desorption kinetic studies, pseudo-second order, pore diffusion and intraparticle diffusion models were applied. The possibility of the reuse of Macronet MN 200 to remove the $\mathrm{LnCr}$ was also evaluated.

\section{EXPERIMENTAL}

\section{Materials}

Purolite International Ltd supplied the sorbent Macronet MN 200. The physical and chemical characteristics are presented in Table 1. Samples were conditioned in methanol-hydrochloric acid mixtures and finally in water before being used on the sorption and desorption experiments.

The tested chromium complex dye ( $\mathrm{LnCr}$ ) was the commercial textile dye anionic Lanasyn Navy M-DNL: the structure Lanasyn Navy M-DNL (1:2 chromium monoazo complex (trisodium bis[3hydroxy-[(2-hydroxy-1-naphthyl)azo] naphthalene-1-sulphonato(3-)] chromate(3-)); the molecular mass $834 \mathrm{~g} / \mathrm{mol} ; \lambda_{\max } 616 \mathrm{~nm}$ (Fig. 1). It was obtained from Clariant Product AG (Schwitzerland). An accurately weighted quantity of the dye was dissolved in deionized water to prepare a stock solution. Experimental solutions of the desired concentrations were obtained by successive dilutions.

The solutions used for regeneration were $99.7 \%$ methanol $\left(M_{r}=32.04\right)$, 95\% ethanol $\left(M_{r}=46.07\right)$ and $99.52 \%$ propanol $\left(M_{r}=60.1\right)$ (Sigma-Aldrich International $\mathrm{GmbH})$. 
Table 1. Physical and chemical characteristics of Macronet MN $200[15,21]$

\begin{tabular}{cc}
\hline Polymer matrix structure & Cross-linked poly(styrene) \\
\hline Physical appearance & Brownish-cream spherical beads \\
\hline Screen size range (US Standard Screen) & $16-50$ mesh \\
\hline Punctional group: & Nonfunctionalized \\
\hline Moisture content & $5 \%$ max. $>1.2 \mathrm{~mm} ;$ \\
\hline Shrink/swell factor & $1 \%$ max. $<0.3 \mathrm{~mm}$ \\
\hline Specific gravity & $55-62 \%$ \\
\hline Surface area & $\pm 5 \%$ maximum \\
\hline Pore volume & $1.04 \mathrm{~g} \mathrm{~cm}^{-3}$ \\
\hline $\mathrm{d} 50$, Meso and Macropores & $1100 \mathrm{~m}^{2} \mathrm{~g}^{-1}$ \\
\hline $\mathrm{d} 50$, micropores & $1.0 \mathrm{~cm}^{3} \mathrm{~g}^{-1}$ \\
\hline pH range (stability) & $72 \mathrm{~nm}^{2}$ \\
\hline
\end{tabular}

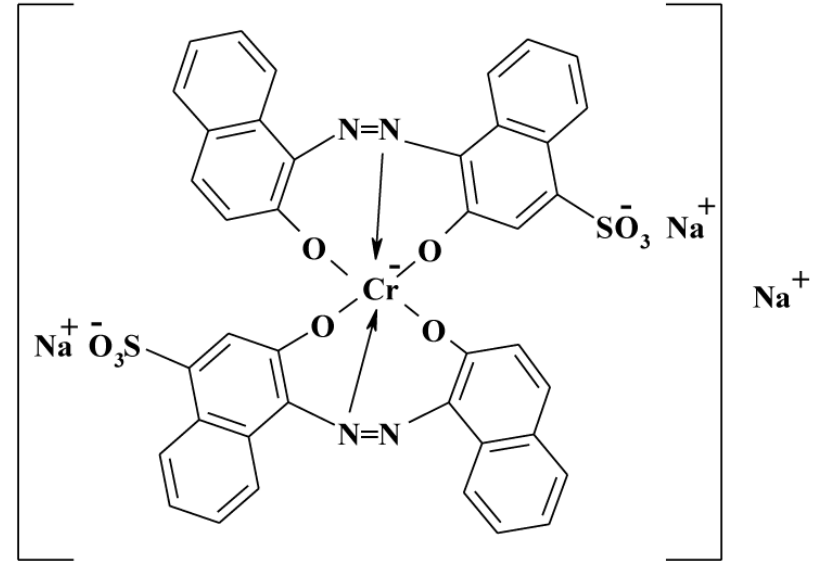

Fig. 1. The structure of Lanasyn Navy M-DNL dye ( $\operatorname{LnCr})$ [24]

\section{Batch experiments}

The potential of alcohol in the desorption of dye was expressed in terms of desorption capacity $q_{\text {des }}(\mathrm{mg} / \mathrm{g})$ and desorption efficiency $D(\%)$ which are given by Eqs. (1) and (2):

$$
\begin{aligned}
& q_{d e s}=\left(C_{d e s} V\right) / m, \\
& D \%=q_{d e s} / q_{a d s} \times 100 .
\end{aligned}
$$

Here $C_{d e s}$ is the concentration of a dye ion in alcohol after desorption $(\mathrm{mg} / \mathrm{L}), V$ is the volume of alcohol(L), $m$ is the mass of a dye-loaded sorbent $(\mathrm{g})$ and $q_{a d s}$ is the loaded sorbent capacity $(\mathrm{mg} / \mathrm{g})$.

Before the MN 200 regeneration tests the sample of $0.5 \mathrm{~g}$ sorbent was mixed with $25 \mathrm{~mL}$ of an $83.4 \mathrm{mg} / \mathrm{L}$ dye aqueous solution and shaken in a temperature controlled shaker (Hotech, Model $706)$ at $170 \mathrm{rpm}$ and $20^{\circ} \mathrm{C}$ for $1 \mathrm{~h}$.

After $1 \mathrm{~h}$, the samples were centrifuged and the residual concentration of dye in the solution was ascertained by a UV-Vis Spectrometer Cintra 101 (GBS Scientific Equipment (USA) LLS) at the respective $\lambda_{\max }$ value, which is $616 \mathrm{~nm}$ for this dye. The dye concentration was calculated from the calibration curve.

The residual colour, Res (\%), was calculated by comparing the absorption $(A)$ of the treated sample with a reference treated identically, but without a sorbent:

$$
\operatorname{Res}(\%)=A(\text { sample }) \cdot 100 \% / A(\text { reference }) \text {. }
$$

This was necessary because the molar extinction coefficient of the dyes changes with $\mathrm{pH}$.

Residual concentrations were calculated by multiplying the residual colour with the original concentration

$$
C=\operatorname{Res} \cdot C_{0} \text {, }
$$

where $C_{0}(\mathrm{mg} / \mathrm{L})$ is the initial concentration and $C(\mathrm{mg} / \mathrm{L})$ is the residual concentration of the dye.

The sorption capacity of the sorbent $\left(q_{a d s}, \mathrm{mg} / \mathrm{g}\right)$ or the desorption capacity $\left(q_{d e s}, \mathrm{mg} / \mathrm{g}\right)$ is calculated as follows:

$$
q_{\text {ads/des }}=\left(C_{0}-C_{e}\right) V / m \text {. }
$$


The separated MN 200 particles were added to $250 \mathrm{~mL}$ glass-flasks, filled with $15 \mathrm{~mL}$ of the corresponding alcohol and then shaken for $1 \mathrm{~h}$ at $150 \mathrm{rpm}$ for dye desorption. After filtration, the dye concentrations in the solutions were measured to calculate the amount of the dye in the MN 200.

The infrared spectra of the unloaded and dyeloaded MN 200 were obtained by use of a Fourier transform infrared (FTIR) spectrometer (PerkinElmer Instruments) in the range $4000-650 \mathrm{~cm}^{-1}$. Before that the MN 200 samples unloaded and dyeloaded (under the batch experimental conditions) were dried during $4 \mathrm{~h}$ at $40^{\circ} \mathrm{C}$ in a convectional drier and were held in a vacuum-desiccator over freshly calcinated calcium chloride.

Repetitive measurements yielded the reproducibility at the mean relative deviation $-d /-x 100 \% £ 2$ and the standard relative deviation $s /-x 100 \% £ 2.5$.

\section{Column experiments}

The column experiments were performed in a $1-\mathrm{cm}$ diameter column filled with $8 \mathrm{~mL}$ of swollen MN 200. The dye solutions were passed through the MN 200 bed at a volume velocity of $1 \mathrm{~mL} / \mathrm{cm}^{2} \mathrm{~min}$ (linear flow velocity $1.7 \cdot 10^{-4} \mathrm{~m} / \mathrm{s}$ ). The samples were automatically taken from the effluent at preset time intervals for determination of the effluent concentration.
The saturated column was then regenerated with methanol, followed by washing with deionized water for the next adsorption cycle. In the column tests, the effluent samples were collected and the $\mathrm{LnCr}$ concentration was measured. The MN 200 capacity in each cycle was calculated from the breakthrough curve up to $C / C_{0}=0.5$ and the regeneration efficiency $\left(R_{e}\right)$ was calculated according to the following equation

$$
R_{e}(\%)=\left(q_{i} / q_{0}\right) \cdot 100 \%,
$$

where $q_{0}(\mathrm{mg} / \mathrm{g})$ and $q_{i}(\mathrm{mg} / \mathrm{g})$ are the fresh column capacity and the regenerated column capacity $(\mathrm{mg} / \mathrm{g})$, respectively.

\section{RESULTS AND DISCUSSION}

\section{Characterization of the adsorption nature of LnCr dye on Macronet MN 200}

The comparison of measured FTIR spectra of the LnCr dye (Fig. 2), unloaded and LnCr dye-loaded at $\mathrm{pH}=2$ Macronet MN 200 (Fig. 3), revealed the nature of $\mathrm{LnCr}$ dye adsorption on Macronet MN-200. The wave numbers for the dominant peak from the FTIR spectra are presented in Table 2.

The characteristic peaks for the $\mathrm{LnCr}$ dye (Fig. 2, Table 2) are as follows: average intensity at $1458 \mathrm{~cm}^{-1}$

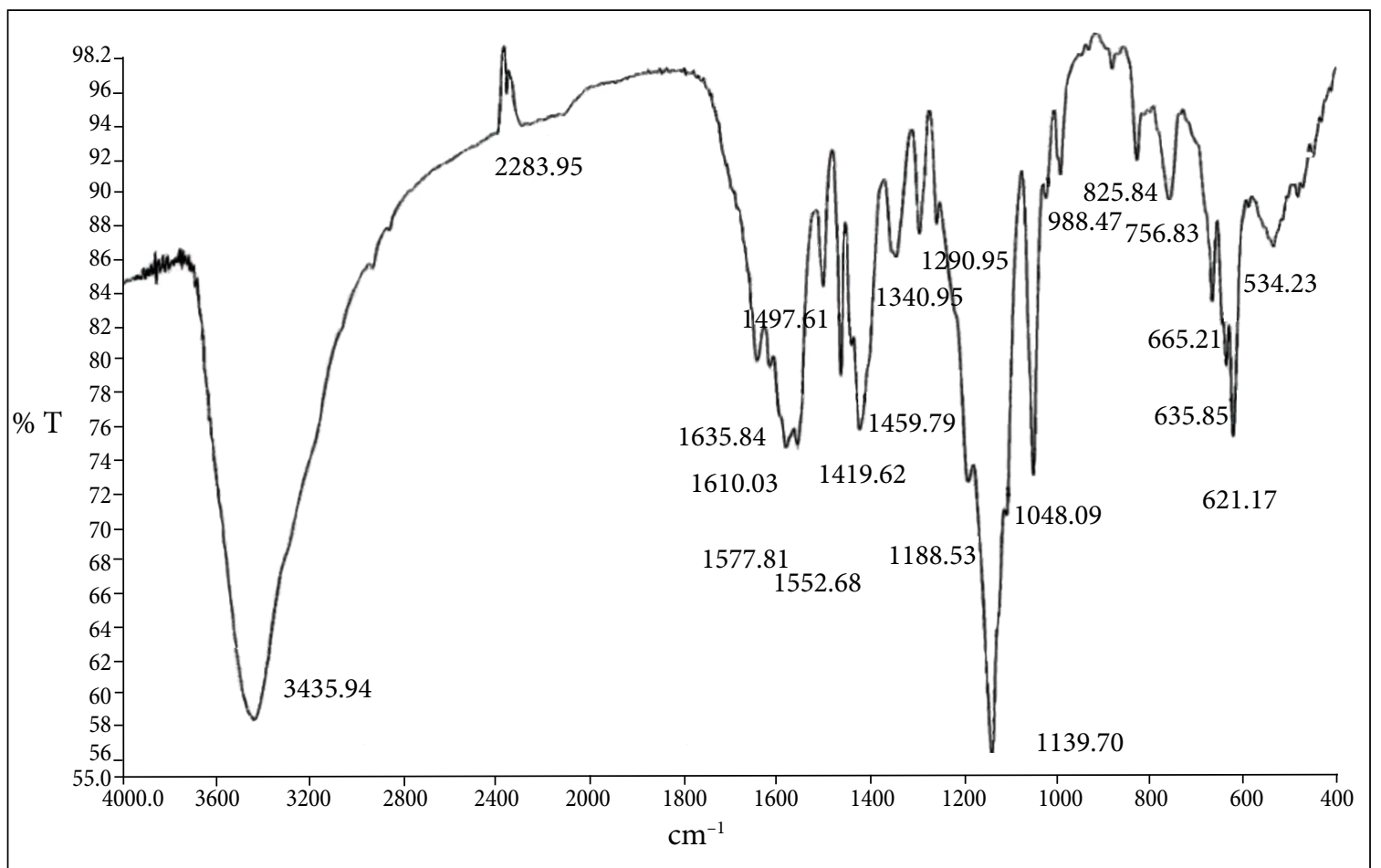

Fig. 2. FTIR spectra of $\operatorname{LnC} r$ dye 
Table 2. Wave number $\left(\mathrm{cm}^{-1}\right)$ for the dominant peak from FTIR for $\mathrm{LnCr}$ dye sorption onto Macronet MN 200 at $\mathrm{pH}=2$

\begin{tabular}{|c|c|c|c|}
\hline Functional group & LnCr dye & Purolite MN 200 unloaded & Purolite MN 200 dye-loaded \\
\hline$-\mathrm{OH}$ & & 3503 & 3476 \\
\hline $\mathrm{C}-\mathrm{H}$ & & 1470-1380; 900-650 & 1470-1380; 900-650 \\
\hline $\mathrm{C}-\mathrm{H}_{2}$ & & $1435-1440$ & $1435-1440$ \\
\hline$C=O$ & & 1678 & 1674 \\
\hline $\mathrm{C}-\mathrm{O}$ & 1140 & 1604 & 1606 \\
\hline $\mathrm{C}-\mathrm{N}$ & 1459 & & 1451 \\
\hline$C=C$ & 1419 & & \\
\hline $\mathrm{N}=\mathrm{N}$ & 1578 & & \\
\hline $\mathrm{N}-\mathrm{N}$ & 1289 & & 1289 \\
\hline$-\mathrm{SO}_{3}-$ & 1048 & & 1044.01 \\
\hline
\end{tabular}

(corresponding to matrix C-N groups), medium intensity at $1419 \mathrm{~cm}^{-1}$ (corresponding to matrix $\mathrm{C}=\mathrm{C}$ groups), medium intensities at 1578 and $1553 \mathrm{~cm}^{-1}$ (corresponding to matrix $\mathrm{N}=\mathrm{N}$ groups), medium intensities at 1289 and $1340 \mathrm{~cm}^{-1}$ (corresponding to matrix $\mathrm{N}-\mathrm{N}$ groups), with mean intensity at $1140 \mathrm{~cm}^{-1}$ (corresponding to matrix $\mathrm{C}-\mathrm{O}$ - groups) and medium intensity at $1048 \mathrm{~cm}^{-1}$ (corresponding to $\mathrm{SO}_{3}{ }^{-}$groups).

The FTIR spectrum of the unloaded MN 200 characterizes the vibration of matrix $\mathrm{CH}, \mathrm{CH}_{2}$ and benzene ring bonds. The vibrations of aromatic rings $\mathrm{C}-\mathrm{H}$ are $1470-1380 \mathrm{~cm}^{-1}$ and $900-650 \mathrm{~cm}^{-1}$. Aliphatic $\mathrm{CH}_{2}$ is captured in the $1435-1440 \mathrm{~cm}^{-1}$ region (Table 2, Fig. 8 a). The vibration of phenol groups $-\mathrm{OH}$ is at $3503 \mathrm{~cm}^{-1}, \mathrm{C}=\mathrm{O}$ at $1678 \mathrm{~cm}^{-1}$ and $\mathrm{C}-\mathrm{O}$ at $1604 \mathrm{~cm}^{-1}$.

In the spectra of MN200 loaded with the $\mathrm{LnCr}$ dye are displacements of the peaks in the phenol groups $(-\mathrm{OH}, \mathrm{C}=\mathrm{O}, \mathrm{C}-\mathrm{O})$, and the peak of the characteristic peaks of the sorbent matrix $(\mathrm{CH})$ expresses the characteristic peaks of the $\mathrm{LnCr}$ dye: $1451 \mathrm{~cm}^{-1}(\mathrm{C}-\mathrm{N}), 1289 \mathrm{~cm}^{-1}(\mathrm{~N}-\mathrm{N}), 1044$ and $1030.71 \mathrm{~cm}^{-1}\left(-\mathrm{SO}_{3}^{-}\right)$(Table 2, Fig. $3 \mathrm{~b}$ ).

Hence the $\mathrm{LnCr}$ dye adsorption on Macronet MN 200 proceeds by physical sorption involving the $\pi-\pi$ interaction and the electrostatic interactions involving $\mathrm{LnCr}$ dye anions. The polymer matrix of MN200 is hydrophobic, but the presence of carbonyl and alkyl aryl ether on the polymer structure proved a partial hydrophilic character that favoured the sorption of dye anions.

\section{LnCr dye desorption in batch experiments}

The sorption behaviour of the $\mathrm{LnCr}$ dye from an aqueous solution onto Macronet MN 200 as an activated carbon AC alternative was investigated under various experimental conditions [25, 26]. The adsorption capacity of Macronet MN 200 for the $\mathrm{LnCr}$ dye was found to be relatively higher than that for AC in both acidic and neutral solutions. However, desorption of the MN-200 loaded with the LnCr dye becomes economically affordable because it does not only regenerate an adsorbent, but also can return the dye back into the dyeing process.

Due to the effectiveness of desorption of activated carbons from the dye by alcohols [19, 27] and the recommendation for MN 200 [21] we chose alcohols with different molecular sizes: methanol, ethanol and 2-propanol for desorption of the LnCr dye from the loaded MN 200.

As shows Fig. 4, the desorption efficiency depended on the alcohol molecular mass and on the amount of the dye adsorbed on MN 200. The desorption efficiency decreases with an increase of alcohol molecular mass: methanol $\left(M_{r}=32\right)>$ ethanol $\left(M_{r}=46\right)>2$-propanol $\left(M_{r}^{r}=60\right)$. This is because a smaller molecule can penetrate into the pores of MN 200 and displaces the $\mathrm{LnCr}$ dye more easily [28]. Meanwhile, a higher desorption efficiency is obtainable if MN 200 was more loaded with the LnCr dye. Figure 4 shows the most effective desorption obtained for all alcohols for MN 200 saturated $4.5 \mathrm{mg} / \mathrm{g}$ compared to the less saturated $3.12 \mathrm{mg} / \mathrm{g}$. 


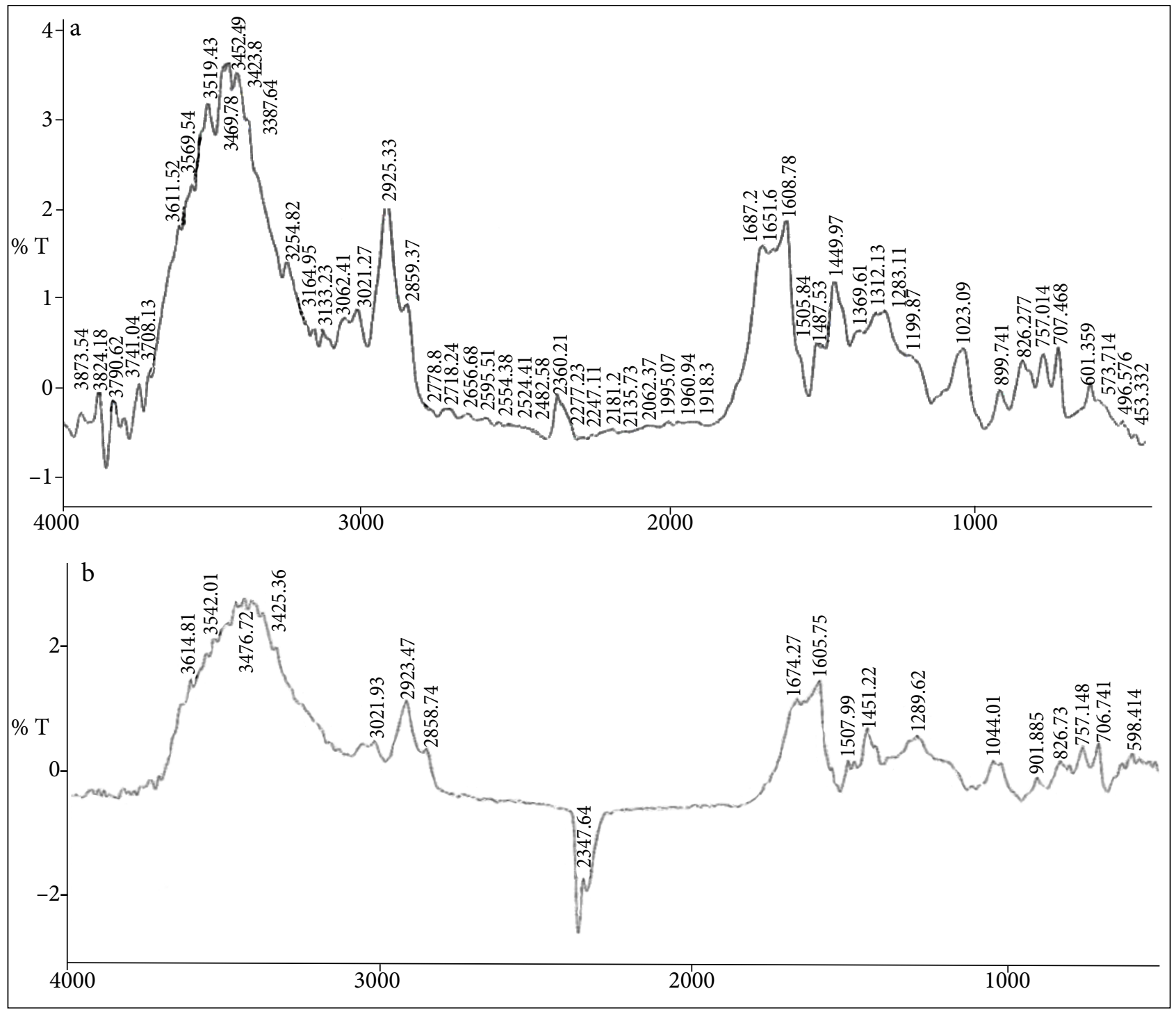

Fig. 3. FTIR spectra of Macronet MN 200: unloaded (a) and LnCr dye-loaded (b)

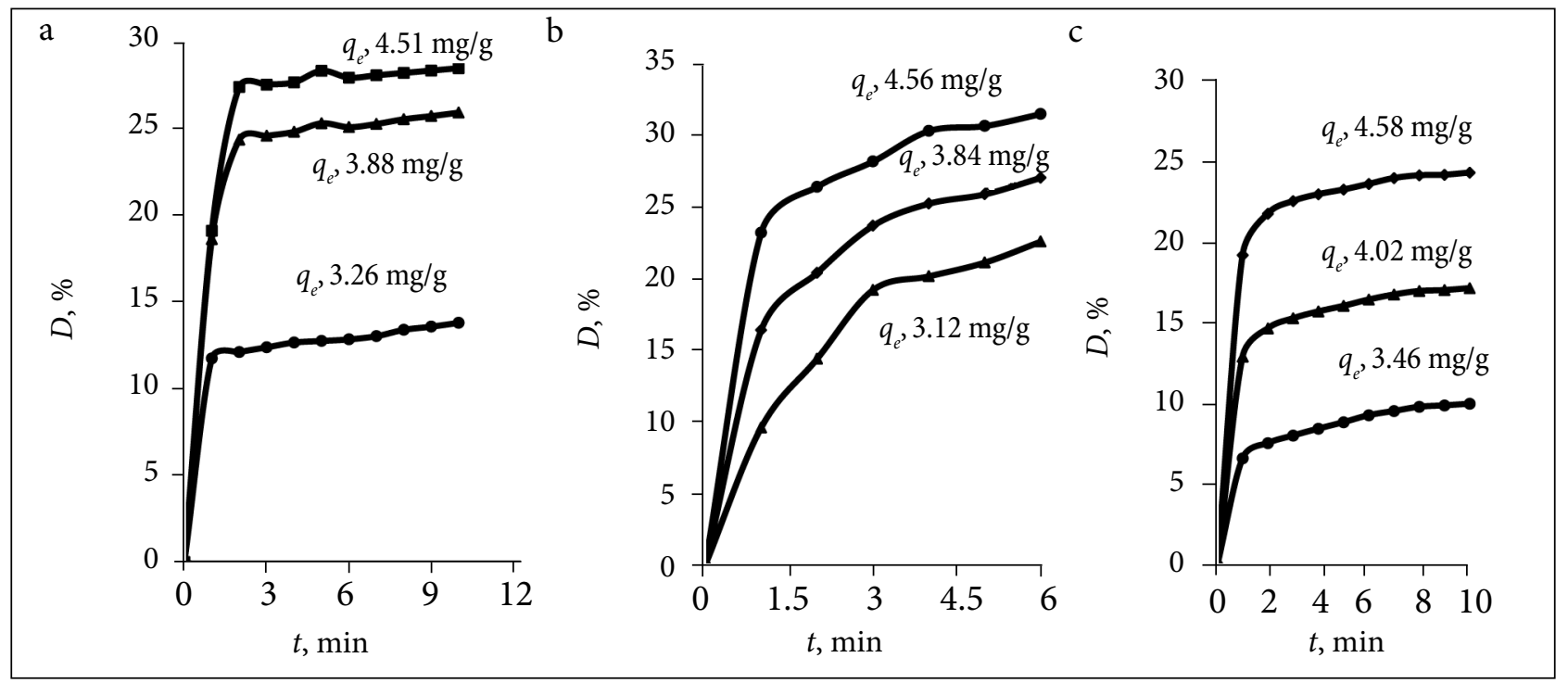

Fig. 4. Desorption efficiency $(D, \%)$ of the $\operatorname{LnC} r$ dye by alcohols from dye-saturated Macronet MN $200\left(q_{e}\right)$ : methanol (a); ethanol (b); 2-propanol (c) 
Furthermore, the desorption efficiency depends on the experimental conditions, i.e. the concentration of the sorbent $(S)$ and sorbate in the solution $(L)$ expressed as a solid/liquid ratio $S / L$. Figure 5 indicates that the desorption efficiency decreases with the $S / L$ decrease. The $\mathrm{LnCr}$ dye was most efficiently desorbed at $S / L=0.033$, i.e. $0.5 \mathrm{~g} \mathrm{MN} 200$ in $15 \mathrm{~mL}$ of methanol $(D=28.6 \%)$, ethanol $(D=30.7 \%)$ and 2-propanol $(D=23.3 \%)$. It was established that the $\mathrm{LnCr}$ desorption efficiency can be increased by gradually adding of three $15 \mathrm{~mL}$ alcohol portions successively. It allows the desorption efficiency to increase up to $66.8 \%$ using methanol, $77.7 \%$ using ethanol and $48.3 \%$ using 2-prophanol. Therefore, the $\mathrm{LnCr}$ dye desorption efficiency must be tested in the column experiment.

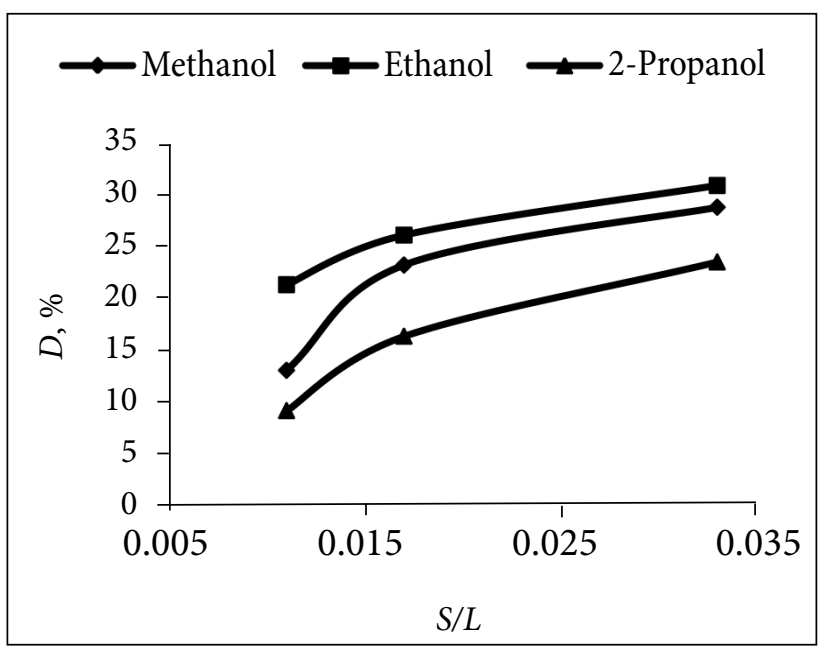

Fig. 5. Effect of $S / L$ on the desorption efficiencies of the $\operatorname{LnCr}$ dye from MN 200

\section{Desorption kinetic rate and diffusion constants}

Desorption can be described as breaking of the surface bonds that bind the adsorbate molecule. In order to quantify the rates of desorption obtained in the Macronet MN 200 desorption experiments, it was necessary to ascertain a suitable desorption kinetic model. On the assumption that the amount of alcohol diffused into pores of MN 200 is equal to that of $\mathrm{LnCr}$ dye diffused from pores into the solution, the experimental data were analysed using pseudo-second-order [29, 30], pore diffusion [31] and intraparticle diffusion [32, 33. models. The linear forms of the applicable kinetic model equation are given in Table 3 .
The calculated second-order kinetic parameters for adsorption and desorption of the $\mathrm{LnCr}$ dye are given in Table 4 . The calculated correlation coefficients $\left(R^{2}\right)$ for adsorption as well as for desorption have considerable values for the pseudo-second-order kinetic model, which confirms a good compliance of the former model with the experimental data.

The pseudo-second-order rate constant $k_{2}$ for LnCr dye desorption from MN 200 was 7.8 times higher than $k_{2}$ for LnCr dye adsorption because $\mathrm{LnCr}$ dissolves in alcohol better than in water, but the amount of the desorbed $\mathrm{LnCr}$ dye is 2.3 times lower.

The surface area and pore size distribution of the Macronet MN 200 significantly influenced the adsorption-desorption capacity and kinetics (Fig. 4). Macronet MN 200 is characterized by a very high pore area of $697.17 \mathrm{~m}^{2} / \mathrm{g}$ with an average pore diameter of $5.19 \mathrm{~nm}$, including macropores and mezopores $72 \mathrm{~nm}$ in size and micropores $1.6 \mathrm{~nm}$ in size [34]. It is assumed that the size of dye molecules usually is in a range of 1-2 nm, whereas the size of alcohol molecules is considerably smaller (methanol molecule size is $0.36 \mathrm{~nm}$ ). Consequently, the diffusion of a large $\mathrm{LnCr}$ dye molecule into MN 200 macropores and micropores must be different.

The diffusion is described in terms of the occurring processes: diffusion of the adsorbate/desorbate in the liquid, adsorption or desorption between the liquid and solid phases, and surface diffusion of the adsorbate/desorbate. To obtain a deep understanding on the characteristics of the desorption process pore diffusion and intraparticle diffusion models were applied to fit to the experimental data. The diffusivity rate $\left(D / r^{2}\right)$ used in the pore diffusion model equation is valid for a short time when the concentration of the regenerating solution remains essentially unchanged (Table 4). The pore model linear plots for regenerating alcohols are presented in Fig. 6 and the obtained pore model parameters are given in Table 5 .

It can be seen from Table 5 that the diffusivity decreases like the desorption efficiency with an increase of alcohol molecular weight (Fig. 4): methanol $(\mathrm{MW}=32)>$ ethanol $(\mathrm{MW}=46)>2$-propanol $(\mathrm{MW}=60)$. That confirmed that a smaller molecule can penetrate into the pores of MN 200 and displaces the $\mathrm{LnCr}$ dye more easily. 
Table 3. Linear expressions of adsorption kinetic models

\begin{tabular}{|c|c|c|c|}
\hline Kinetic model & Linear expression & Plot order & Parameters \\
\hline $\begin{array}{l}\text { Pseudo-second- } \\
\text { order }[29,30]\end{array}$ & $\begin{array}{l}\qquad \frac{t}{q_{t}}=\frac{1}{k_{2} q_{e q, \text { calc }}^{2}}+\frac{1}{q_{e q, \text { calc }}} t \\
\text { where } q_{t} \text { and } q_{e q} \text { are the amount } \\
\text { of the dye in the solution at time } t\end{array}$ & $t / q_{t}$ vs $t$ & $\begin{array}{c}q_{\text {eq,alc }}=1 / \text { slope } \\
\text { The pseudo-second-order rate constant } \\
k_{2}=\text { slope }^{2} / \text { intercept }\end{array}$ \\
\hline $\begin{array}{l}\text { Pore diffusion } \\
\text { model [31] }\end{array}$ & $\frac{q_{t}}{q_{e q}}=6 \sqrt{\frac{D t}{r^{2} \pi}}$ & $\frac{q_{t}}{q_{e q}} \operatorname{vs} \sqrt{t}$ & $\begin{array}{c}6 / \mathrm{r} \sqrt{D / \pi}=\text { slope; } D\left(\mathrm{~m}^{2} / \mathrm{min}\right) \text { is the diffusivity } \\
\text { of the sorbate within the sorbent pores; } \\
r \text { is the radius of the sorbent }\end{array}$ \\
\hline $\begin{array}{l}\text { Intraparticle diffu- } \\
\text { sion (Weber and } \\
\text { Morris) }[32,33]\end{array}$ & $\begin{array}{l}q_{t}=k_{i}\left(t^{0.5}\right)+B \\
\text { where } q_{t} \text { is the amount of the dye } \\
\text { in the solution at time } t\end{array}$ & $q_{t}$ vs $t^{0.5}$ & $\begin{array}{l}\text { The intraparticle diffusion rate constant } \\
\qquad k_{i}=\text { slope } \\
\text { The boundary layer thickness } B=\text { intercept }\end{array}$ \\
\hline
\end{tabular}

Table 4. The parameters of pseudo-second-order kinetic $\left(k_{2}, q_{a d s}\right)$, correlation coefficients $\left(R^{2}\right)$ obtained for the adsorption and desorption of the $\mathrm{LnCr}$ dye. Adsorption: MN 200 mass $0.5 \mathrm{~g}$; volume of solution $25 \mathrm{ml}$; $C_{0}=83.4 \mathrm{mg} / \mathrm{L}$. Desorption: MN 200 mass $0.5 \mathrm{~g}$; volume of solution $15 \mathrm{~mL}$

\begin{tabular}{c|c|c|c}
\hline & $\boldsymbol{k}_{\mathbf{2}} \mathbf{g} / \mathbf{m g ~} \mathbf{m i n}$ & $\boldsymbol{q}_{\text {ads }} / \boldsymbol{q}_{\text {des }}$ & $\boldsymbol{R}^{\mathbf{2}}$ \\
\hline \multicolumn{5}{c}{ Adsorption } \\
\hline Adsorbat 83.4 mg/L LnCr & $q_{\text {ads }}=0.97 \mathrm{mg} / \mathrm{g}$ & 0.9998 \\
\hline Methanol & 1.96 & & 0.9999 \\
\hline
\end{tabular}

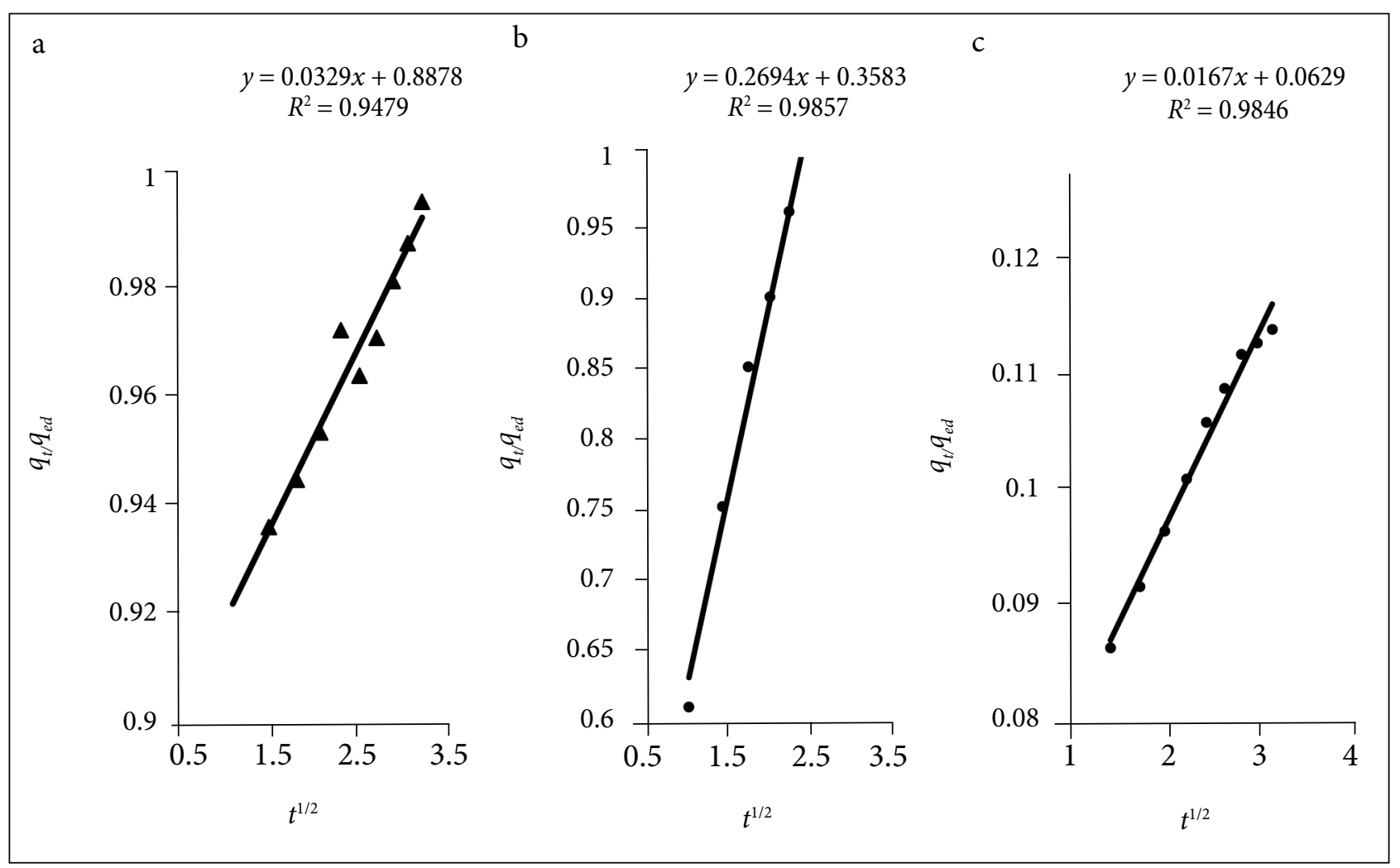

Fig. 6. Pore diffusion model for LnCr dye desorption from MN 200 using alcohols: methanol (a); ethanol (b); 2-propanol (c) 
Table 5 . Diffusivity rate $\left(D / r^{2}\right)$ for $L N C r$ dye calculated according to the pore diffusion mode

\begin{tabular}{cc|cc}
\hline Alcohol & Amount of adsorbed dye, $\left.\boldsymbol{q}_{\text {ads }} \mathbf{( m g} / \mathbf{g}\right)$ & Pore diffusion model parameter, $\mathbf{D} / \mathbf{r}^{\mathbf{2}} \cdot \mathbf{1 0}^{\mathbf{4}}, \mathbf{~ m i n}^{\mathbf{- 1}}$ & $\boldsymbol{R}^{\mathbf{2}}$ \\
\hline Methanol & 3.26 & 89.3 & 0.9479 \\
\hline Ethanol & 3.84 & 63.3 & 0.9857 \\
\hline 2-Propanol & 3.46 & 30.4 & 0.9846 \\
\hline
\end{tabular}

The effect of the MN 200 pore size on desorption efficiency has been studied using the intraparticle diffusion model. According to the above-mentioned intraparticle diffusion model the plot of $q_{t}$ versus the square root of time $\left(t^{0.5}\right)$ would be linear if intraparticle diffusion was involved in the desorption process, and if these lines passed through the origin, intraparticle diffusion would be the rate determining step [33]. However, the plots obtained for LnCr dye desorption from MN 200 show two different linearity profiles with different slopes $\left(k_{i-1}\right.$ and $k_{i-2}$ ) (Fig. 7) suggesting that the intraparticle diffusion is not the rate limiting step for the whole process. The rate constants for the intraparticle diffusion values $k_{i-1}$ and $k_{i-2}$ are presented in Table 6 .

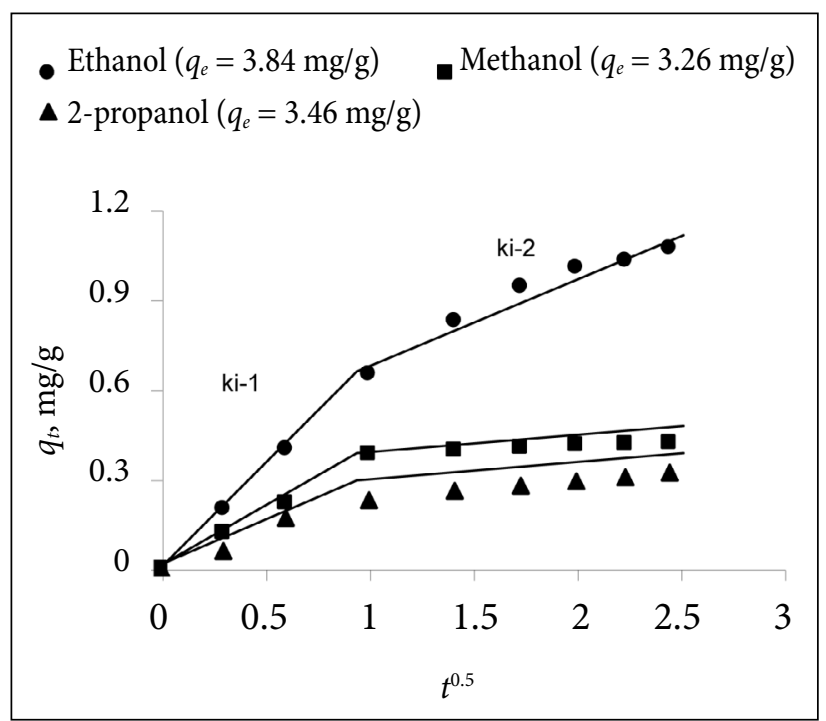

Fig. 7. Intraparticle diffusion model for $\operatorname{LnC} r$ dye desorption from MN 200
The first steep linear portion of plots $q_{t}$ against $t^{0.5}$ can be attributed to the diffusion of $\mathrm{LnCr}$ through the solution from the external surface of resin and from macropores and mezopores (intraparticle diffusion rate constant $k_{i-1}$ ). The second section is the gradual desorption stage, where intraparticle diffusion is rate controlled (intraparticle diffusion rate constant $k_{i-2}$ ) [34]. The larger slopes of the first sharp linear portion $\left(k_{i-1}\right)$ indicate that the rate of $\mathrm{LnCr}$ dye desorption is higher at the initial stage due to the instantaneous availability of a large surface area. The lower slopes of the second linear portion $\left(k_{i-2}\right)$ are due to the long $\mathrm{LnCr}$ dye diffusion from the micropores of $\mathrm{MN} 200$, thus leading to a low dye removal rate.

The values of intercept $B$ indirectly represent the boundary layer effect [35]. Thus, the larger value of the intercept $B_{2}$ than that of $B_{1}$ obtained for MN 200 shows a more pronounced effect on the intraparticle diffusion stage that controls the desorption rate (Table 6).

\subsection{LnCr dye desorption in column experiments} Adsorption-desorption experiments in the column were performed to test the MN 200 adsorption capacity after regeneration with methanol.

A typical breakthrough curve for the $83.4 \mathrm{mg} / \mathrm{l}$ LnCr dye feed concentration $\left(C_{f}\right)$ and the desorption curve by methanol are shown in Fig. 8. The bed adsorption capacity can be calculated from the adsorption breakthrough curve shown in Fig. 8 a. As show Fig. $8 \mathrm{~b}$ and Fig. 9, a very high dye concentration about $4 \mathrm{~g} / \mathrm{L}$ was obtained within the first

Table 6. Intraparticle diffusion parameters and correlation coefficients obtained for the desorption of $\mathrm{LnCr}$ dye. Conditions: adsorbent mass $0.5 \mathrm{~g}$, volume of solution $15 \mathrm{~mL}$

\begin{tabular}{|c|c|c|c|c|c|c|}
\hline Alcohol & $k_{i-1}, \mathrm{mg} / \mathrm{g} \mathrm{min}^{0.5}$ & $B_{i-1}, \mathrm{mg} / \mathrm{g}$ & $R_{i-1}^{2}$ & $\mathrm{k}_{i-2^{\prime}} \mathrm{mg} / \mathrm{g} \mathrm{min}^{0.5}$ & $B_{i-2}, \mathrm{mg} / \mathrm{g}$ & $R_{i-2}^{2}$ \\
\hline Methanol & 0.3801 & 0.0005 & 0.9985 & 0.0256 & 0.3598 & 0.9814 \\
\hline Ethanol & 0.6507 & 0.0034 & 0.9985 & 0.0295 & 0.3761 & 0.9799 \\
\hline 2-Propanol & 0.2391 & 0.0011 & 0.9708 & 0.0613 & 0.1704 & 0.9946 \\
\hline
\end{tabular}




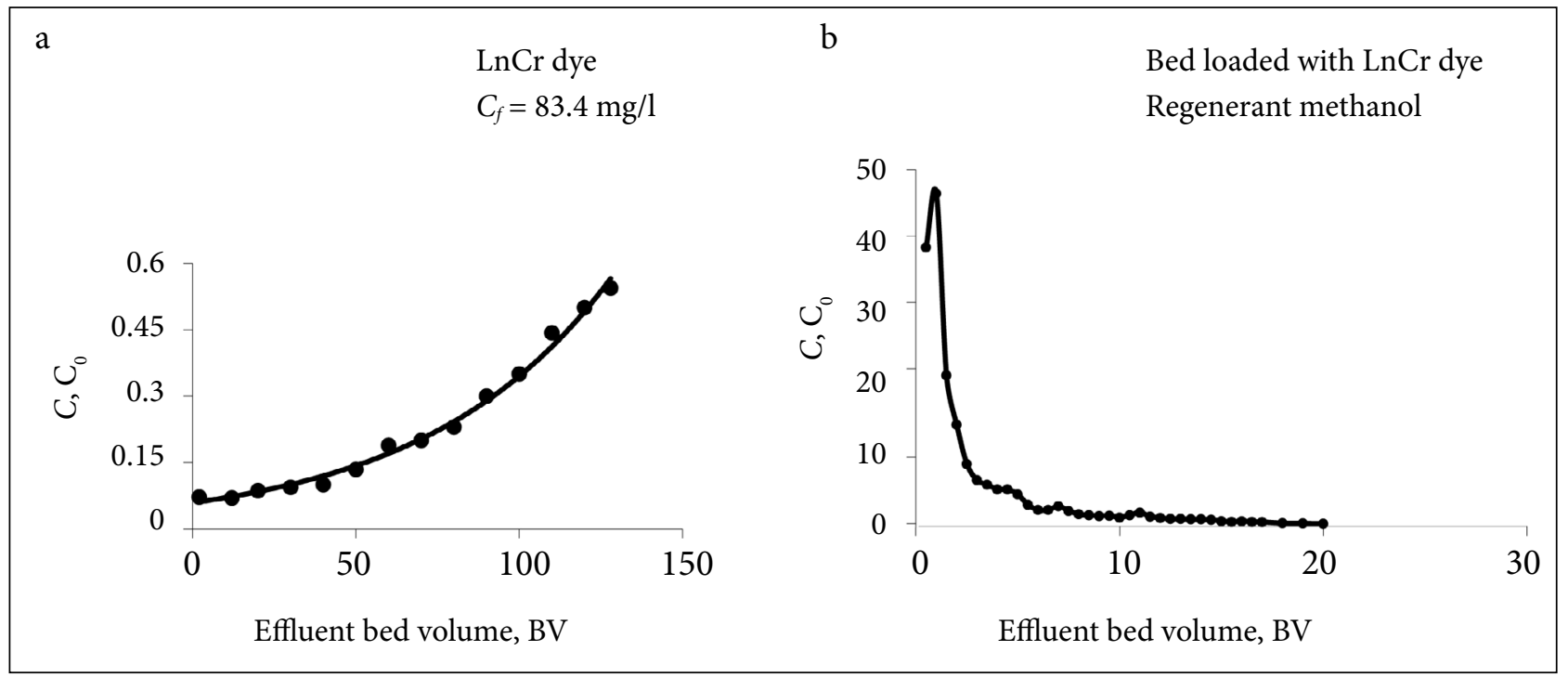

Fig. 8. Typical dye adsorption breakthrough curve (a) and desorption curve (b) of column operation

2 methanol bed volumes (BV = volume of methanol/volume of MN 200) and the LnCr dye was desorbed back to the solution with 10 methanol BV.

The regeneration efficiency of $\mathrm{LnCr}$ dye-loaded MN $200\left(R_{e}\right)$ using methanol with repeated adsorption desorption cycles decreased but seems to be stabilized after 3 cycles to $R_{e}=70 \%$. The reason of the adsorption capacity decrease of the regenerated MN 200 column can be that methanol cannot completely substitute $\mathrm{LnCr}$ dye anions adsorbed through the electrostatic interaction. Another reason may be that methanol molecules occupied the MN 200 surface sites that become unavailable for the $\mathrm{LnCr}$ dye adsorption in the next cycle. Similar observations were published in literature [27, 36].

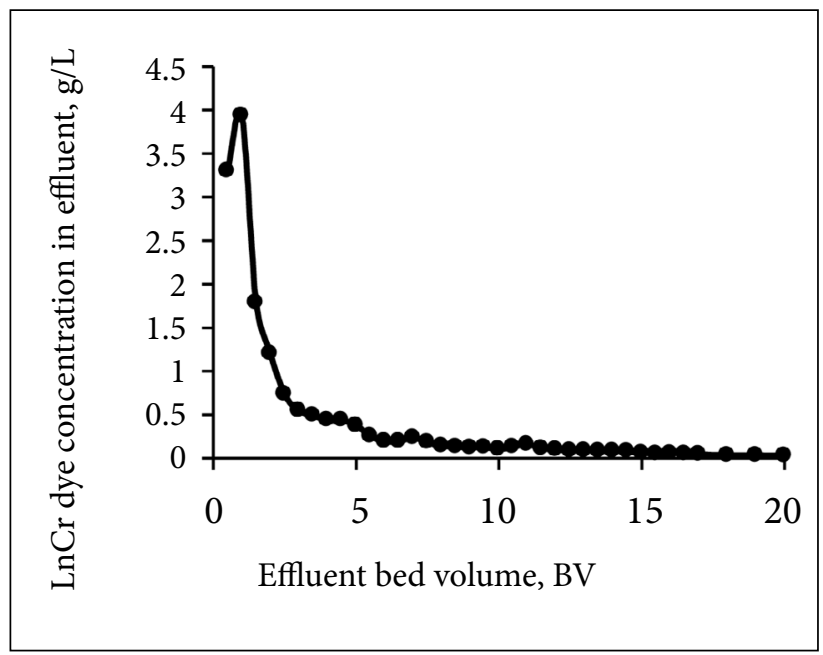

Fig. 9. LnCr dye concentration in effluent (methanol)
After the regeneration of adsorbents, the used solvent containing the adsorbate was distilled and the solvent was used again for regeneration. This is a typical process of solvent regeneration.

\section{CONCLUSIONS}

A series of batch and column experiments were performed to desorb the $\mathrm{LnCr}$ metal complex dye using various alcohols from the nonfunctional Macronet MN 200. The batch desorption results show decreases in the desorption efficiency with a solid/liquid ratio $S / L$ decrease and with an increase of molecular weight (methanol $>$ ethanol > 2-propanol). The desorption rate has been assessed by pseudo-second order, pore diffusion and intraparticle diffusion models. The adsorption capacities of the Macronet MN 200 bed after the repeated 3 adsorption-desorption cycles dropped to $70 \%$ of their initial capacity.

Received 5 November 2018 Accepted 12 December 2018

\section{References}

1. K. Hunger (ed.), Industrial Dyes. Chemistry, Properties, Application, Wiley-VCH, Weinheim (2003).

2. Clariant Aluminium Finishing https://www.clariant.com/en/Business-Units/Pigments/Special... Aluminium-Finishing].

3. T. Poiger, S. D. Richardson, G. L. Baughman, J. Chromatogr. A, 886, 259 (2000). 
4. V. M. Correia, T. Stephenson, S. J. Judd, Environ. Technol., 15, 917 (1994).

5. S. F. Dubrow, G. D. Boardman, D. J. Michelsen, in: A. Reife, H. S. Freeman (eds.), Environmental Chemistry of Dyes and Pigments, Wiley-Interscience, New York (1996).

6. Environmental Agency, Integrated Pollution Prevention and Control (IPPC), IPPC S6.05, Guidance for the Textile Sector (2002).

7. C. Allegre, P. Moulin, M. Maisseu, G. L. Charbit, J. Membr. Sci., 269, 15 (2006).

8. P. Faria, J. Orfao, M. Pereira, Water Res., 38, 2043 (2004).

9. V. Gomez, M. S. Larrechi, M. P. Calao, Chemosphere, 69, 1151 (2007).

10. R. Moreira, N. Kuhnen, M. Peruch, Lat. Am. Appl. Res., 28, 37 (1998).

11. X. Yang, B. Al-Duri, J. Colloid Interface Sci., 287, 25 (2005).

12. Y. S. Al-Degs, M. I. El-Barghouthi, A. H. El-Sheikh, G. M. Walker, Dyes Pigm., 77, 16 (2008).

13. M. H. Tai, B. Saha, M. Streat, React. Func. Polym. 41, 149 (1999).

14. Z. Y. Hu, Q. X. Zhang, H. P. F. Herbert, Crit. Rev. Environ. Sci. Technol., 33, 363 (2003).

15. M. Streat, L. A. Sweetland, React. Funct. Polym. 35, 99 (1997).

16. V. Davankov, M. Tsyurupa, Compr. Anal. Chem., 56, 166 (1981).

17. A. W. Trochimczuk, M. Streat, B. N. Kolarz, React. Funct. Polym., 46, 259 (2001).

18. G. Z. Kyzas, N. K. Lazaridis, Chem. Eng. J., 248, 327 (2014).

19. F. Salvador, N. Martin-Sanchez, R. SanchezHernandez, M. J. S. Sanchez-Montero, C. Izquierdo, Microporous Mesoporous Mater., 202, 277 (2015).

20. M. A. M. Salleh, D. K. Mahmoud, W. A. Karim, A. Idris, Desalination, 280(1), 1 (2011).

21. Macronet MN200. Product Data Sheet https://www. purolite.com/product-pdf/MN200.pdf].

22. C. Valderrama, J. L. Cortina, A. Farran, X. Gamisans, F. X. de las Heras, React. Funct. Polym., 68, 679 (2008).

23. M. Wawrzkiewicz, Chem. Eng. J., 217, 414 (2013).

24. Ch. Y. Kim, H. M. Choi, H. T. Cho, J. Appl. Polym. Sci., 63, 725 (1998).

25. D. Kaušpèdienè, E. Kazlauskienè, A. Gefenienė, R. Binkienè, J. Hazard. Mater., 179, 933 (2010).

26. E. Kazlauskiene,, D. Kaušpèdienè, A. Gefenienè, A. Selskienè, R. Binkienè, Chemija, 20(2), 69 (2009).

27. P.-J. Lu, H.-Ch. Lin, W.-T. Yu, J.-M. Chern, J. Taiwan Inst. Chem. Eng., 42, 305 (2011).
28. R. J. Martin, W. J. Ng, Water Res., 19, 1527 (1985).

29. Y. S. Ho, J. Hazard. Mater., B136, 681 (2006).

30. Sh. Wang, H. Li, Dyes Pigm., 72, 308 (2007).

31. B. Özkaya, J. Hazard. Mater., B129, 158 (2006).

32. W. J. Weber, J. C. Morris, J. Sanitary Eng. Div. Am. Soc. Civ. Eng., 89, 31 (1963).

33. S. J. Allen, G. McKay, K. Y. H. Khader, Environ. Pollut., 56(1), 39 (1989).

34. W. Yang, X. Xue, F. Zheng, Y. Xiaodi, Sep. Sci. Technol., 46(8), 1321 (2011).

35. W. H. Cheung, Y. S. Szeto, G. McKay, Bioresour. Technol., 98, 2897 (2007).

36. V. K. A. Gupta, A. Mittal, V. Gajbe, J. Mitall, J. Colloid Interface Sci., 319, 30 (2008).

Danutė Kaušpėdienè, Audronė Gefenienė,

Romas Ragauskas, Rima Binkienė

\section{NEJONINIO POLIMERINIO SORBENTO MACRONET MN 200, PRISOTINTO METALO- KOMPLEKSINIU DAŽIKLIU, REGENERAVIMAS STATINĖMIS IR DINAMINĖMIS SALYGOMIS NAUDOJANT ALKOHOLIUS}

Santrauka

Ištirtos sorbento Macronet MN 200 daugkartinio naudojimo galimybès pašalinant metalo kompleksini dažikli Lanasyn Navy M-DNL ( $\mathrm{LnCr}$ ) iš vandeninių tirpalų. Prisotintas LnCr dažikliu Macronet MN 200 buvo regeneruotas alkoholiais (metanoliu, etanoliu, 2-propanoliu) statinèmis ir dinaminėmis sąlygomis.

Išmatuotas Macronet MN 200, prisotinto $\mathrm{LnCr}$ dažikliu, FTIR spektras įrode LnCr anijono ir Macronet MN 200 fizikinę sąveiką, dalyvaujant $\pi-\pi$ ir elektrostatiniams ryšiams. Statinèmis sąlygomis LnCr dažiklio desorbcijos efektyvumas priklauso nuo MN 200 masès / LnCr tirpalo tūrio santykio ( $\mathrm{S} / \mathrm{L}, \mathrm{g} / \mathrm{ml}$ ), alkoholio molekulinès masès ir desorbcijos trukmès. Efektyviausiai LnCr dažiklis desorbuojamas per 10 min. esant $S / L=0,033$. Didejjant alkoholio molekulinei masei LnCr desorbcija mažeja: metanolis > etanolis $>2$-propanolis. Desorbcijos greičiai vertinti taikant antrojo laipsnio $\left(k_{2}\right)$, difuzijos porose $\left(D / r^{2}\right)$ ir vidinès difuzijos $\left(k_{i}\right)$ modelius. Dinaminėmis sąlygomis atlikti adsorbcijos / desorbcijos ciklai parode, kad LnCr prisotinto MN 200 regeneracijos efektyvumas naudojant metanoli mažeja, bet po trijų ciklų stabilizuojasi ir išlieka apie 70 \%. Didžiausia LnCr dažiklio koncentracija metanolyje ( $4 \mathrm{~g} / \mathrm{l})$ gaunama panaudojus 2 metanolio tūrius 1 tūriui MN 200, o LnCr dažiklis visiškai desorbuojamas panaudojus 10 metanolio tūrių. 
